\title{
Effect of Aqueous Extract on Total Phenolic Content and Antimitotic Activity of Ficus Benghalensis root on Allium Cepa Root Meristamatic cells
}

\author{
RA Ahirrao ${ }^{1 *}$, BU Jain ${ }^{2}$, PV Jaiswal ${ }^{2}$ and AS Kabra ${ }^{2}$ \\ ${ }^{1}$ Ravindra Nikam College of Pharmacy, India \\ ${ }^{2}$ Students of college of pharmacy, Shahada MS, India
}

*Corresponding author: RA Ahirrao, Ravindra Nikam College of Pharmacy,

Gondur-424002, Dhule, Maharashtra, India.

Received Date: July 30, 2020

Published Date: August 21, 2020

\begin{abstract}
Objective: To evaluate aqueous extract of Ficus Benghalensis Linn. root for Total Phenolic Content and Antimitotic Activity on Allium Cepa Root Meristamatic cells.

Materials and Methods: The Ficus benghalensis Linn. root was extracted with distilled water solvent by maceration method. The plant extract is subjected to study total Phenolic content method. The extract is also tested for their antimitotic activity in Allium cepa root Meristamatic cells.

Result and Conclusion: The preliminary phytochemical screening of aqueous extract of Ficus Benghalensis Linn. root showed presence of high amount of total Phenolic content in $100 \mu \mathrm{g}$ was found to be $13.72 \mu \mathrm{g}$ of gallic acid equivalent. In Allium assay, aqueous extract of Ficus Benghalensis Linn. root $(10 \mathrm{mg} / \mathrm{ml})$ and methotrexate showed significant concentration dependant inhibitory influence against the dividing cells of Allium roots and decreased root growth and mitotic index as compared to control distilled water. The result indicated that antimitotic activity is due to presence of phenolic, alkaloids and flavonoids compounds in $10 \mathrm{mg} / \mathrm{ml}$ concentration of aqueous extract of Ficus Benghalensis root.
\end{abstract}

Conclusion: On the basis of result, we concluded that, $10 \mathrm{mg} / \mathrm{ml}$ concentration of Ficus Benghalensis root shows good antimitotic activity on the Allium cepa root tip assay.

Keywords: Ficus Benghalensis; Allium cepa; Antimitotic; Maceration; Methotrexate

\section{Introduction}

In today's world, peoples are suffered from lots of dangerous diseases. Cancer is one of that disease and second leading cause of death in the world [1]. Now a day, various new anticancer agents are isolated from the natural sources of drugs. Natural sources of drugs are herbal based drugs consists of about $60-80 \%$ of all other drugs and used as medicine from 1990 [2,3]. The active constituent which is isolated from plants play a vital role in treatment of various diseases and gives special attention such herbal based plants due to its pharmacological activities [4]. There are certain plants which are used in treatment of diseases like cancer. It is found that most of isolated compounds from plants show good anticancer activity [5,6]. The Ficus Benghalensis Linn. is 'The national tree of India', is native to India and commonly known as Banyan tree of family Moraceae, which is known as Indian Banayan in English. The 
plant Ficus Benghalensis Linn. shows various pharmacological or medicinal properties like antioxidant, analgesics, anti-asthmatic, anti-inflammatory and anti-diabetic activity [7-9].

The stem barks extract of Ficus Benghalensis Linn. shows good antimitotic and antioxidant activity [10]. Based on review of literature that no work has to be done on antimitotic activity at concentration of $10 \mathrm{mg} / \mathrm{ml}$ of aqueous extracts of Ficus Benghalensis Linn. roots. Hence in this study aqueous extract of Ficus Benghalensis Linn. roots in $10 \mathrm{mg} / \mathrm{ml}$ concentration were assessed by using Allium cepa root meristamatic cells. The $10 \mathrm{mg} /$ ml concentration of aqueous extract of Ficus Benghalensis Linn. roots were taken because to see the effect of Ficus Benghalensis Linn. roots at $10 \mathrm{mg} / \mathrm{ml}$ concentration.

\section{Materials and Methods}

\section{Plant material \& reagents}

Ficus Benghalensis roots were collected from Nandurbar (MS) region and authenticated by Professor S. K. Tayade, Botany Department, College of Art's, Commerce and Science, Shahada, Lonkheda -425409, (MS). Chemicals and reagents are taken from Rajesh Chemicals, Mumbai.

\section{Preparation of roots extract}

Collected roots were washed with distilled water, shade dried and pulverized to a rough form and extraction is done by maceration method using water-chloroform solvent. The filtrate was evaporated by using rotary-evaporator which removed water solvent in vacuum at $40^{\circ} \mathrm{C}$. Take small amount of water extract of Ficus benghalensis Linn. roots and dissolved into small amount of distilled water to produce test solution. This test solution was used to study different chemical tests such as alkaloids, flavonoids, tannins, carbohydrates and proteins for detection of different chemical constituents present in the aqueous extract [11]

\section{Total Phenolic Content [12]}

The total phenolic content of Ficus benghalensis roots was determined by using the Folin-Ciocalteu assay. A stock solution $(1 \mathrm{mg} / \mathrm{ml})$ of the extracts was prepared in methanol. From the stock solution, $1 \mathrm{ml}$ of the extracts of different concentrations ranging from 20 to $100 \mu \mathrm{g} / \mathrm{ml}$ was taken into a $25 \mathrm{ml}$ volumetric flask and $10 \mathrm{ml}$ of water and $1.5 \mathrm{ml}$ of Folin-Ciocalteau reagent was added to it. The mixture was kept for $5 \mathrm{~min}$, and then $4 \mathrm{ml}$ of $20 \%$ sodium bicarbonate solution was added and made up to $25 \mathrm{ml}$ with double-

distilled water. The absorbance was recorded at $765 \mathrm{~nm}$ after 90 min. Percentage of total phenolic was calculated from calibration curve of gallic acid plotted by using the above procedure and expressed $\mu$ g of gallic acid equivalent.

\section{Determination of mitotic index $[13,14]$}

Red qualities of onions (Allium cepa) are purchased from near market area and are stored for further study. The red onion bulbs are place in tap water at room temperature for 48 hours. On the other hand, prepared different solutions at concentration of aqueous extract of Ficus Benghalensis roots at of $10 \mathrm{mg} / \mathrm{ml}$, standard drug methotrexate (Zydus Cadila, Ahmedabad) at $0.1 \mathrm{mg} / \mathrm{ml}$ and distilled water which served as control respectively. The developed roots then dipped in-to solutions of aqueous, methotrexate and distilled water for two hours. Then removed the roots then cut to separate tip part of roots and placed in to fixing solution consists of acetic acid $45 \% \mathrm{v} / \mathrm{v}$ and ethanol $95 \% \mathrm{v} / \mathrm{v}$ in ratio of $1: 3 \mathrm{v} / \mathrm{v}$ for near about 10-15hours. Then roots are reacted with $1 \mathrm{~N}$ HCL and place into oven for $15 \mathrm{~min}$ at $50^{\circ} \mathrm{C}$ for warm of roots. Removed it then washed with distilled water and stain with staining agent like carmine. The roots are then placed on the slides and crushed it and observed under microscope. Count the number of cells present in each stages of mitosis and calculate mitotic index which is as

Mitotic Index $=(\mathrm{P}+\mathrm{M}+\mathrm{A}+\mathrm{T} /$ Total number of cells $) \times 100$

Where $\mathrm{P}$ is Prophase, M is Metaphase, $\mathrm{A}$ is Anaphase and $\mathrm{T}$ is Telophase.

\section{Statistical analysis [15]}

The experiments were carried out in triplicates and the data were expressed as mean \pm SEM. The significance of difference among the various treated cells and control cells were analyzed by means of one-way ANOVA.

\section{Result}

\section{Total Phenolic Content}

The preliminary phytochemical screening of Ficus benghalensis roots showed the presence of high amount of total phenolic and tannins along with flavonoids as shown in Table 1 . The amount of total phenolic content in $100 \mu \mathrm{g}$ of aqueous extract of Ficus benghalensis roots containing $13.72 \mu \mathrm{g}$ of gallic acid equivalent by calibration curve line on measuring absorbance (Table 1) (Figure $1,2)$.

Table 1: Preliminary Phytochemical screening of $10 \mathrm{mg} / \mathrm{ml}$ aqueous extracts of Ficus benghalensis Linn. Root.

\begin{tabular}{|c|c|c|c|}
\hline Sr. No. & Phytochemical Test & Test \\
\hline \multirow{2}{*}{1.} & Test for carbohydrate & Molish test \\
\hline 2. & Test for proteins & Fehling's test \\
\hline 3. & Test for flavonoids & Biuret test \\
\cline { 2 - 3 } & & Lead acetate test \\
\hline
\end{tabular}




\begin{tabular}{|c|c|c|c|}
\hline \multirow{2}{*}{4.} & Test for alkaloids & Dragondroff's test & + \\
\cline { 3 - 4 } & Test for tannins and phenolic compounds & Wagner's test & + \\
\hline \multirow{2}{*}{5.} & Lead Acetate test & + \\
\cline { 3 - 4 } & & Ferric chloride test & + \\
\hline
\end{tabular}

Table 2: Antimitotic activity after treatment of Allium cepa roots with $10 \mathrm{mg} / \mathrm{ml}$ aqueous extracts of Ficus benghalensis Linn. root, methotrexate and control water.

\begin{tabular}{|c|c|c|c|c|c|c|c|c|}
\hline \multirow{2}{*}{$\begin{array}{l}\text { Sr. } \\
\text { No. }\end{array}$} & \multirow{2}{*}{ Different Solutions used for treatment } & \multirow{2}{*}{$\begin{array}{l}\text { Total No. of } \\
\text { cells }\end{array}$} & \multicolumn{4}{|c|}{ No. of Dividing cells } & \multirow{2}{*}{$\begin{array}{l}\text { No. of Non-dividing } \\
\text { cells }\end{array}$} & \multirow{2}{*}{ Mitotic Index } \\
\hline & & & $\mathbf{P}$ & M & A & $T$ & & \\
\hline 1. & Water (Control) & 100 & 30 & 1 & 1 & 4 & 64 & $36 \pm 1.25$ \\
\hline 2. & $\begin{array}{c}\text { Methotrexate } \\
(0.1 \mathrm{mg} / \mathrm{ml} \\
\text { Positive Control) }\end{array}$ & 100 & 26 & 3 & 1 & 0 & 70 & $30 \pm 1.35^{*}$ \\
\hline 3. & $\begin{array}{l}\text { Aqueous Extracts } \\
\qquad(10 \mathrm{mg} / \mathrm{ml})\end{array}$ & 100 & 18 & 2 & 1 & 1 & 78 & $22 \pm 1.15^{*}$ \\
\hline
\end{tabular}

P-Prophase, M-Metaphase, A- Anaphase, T-Telophase

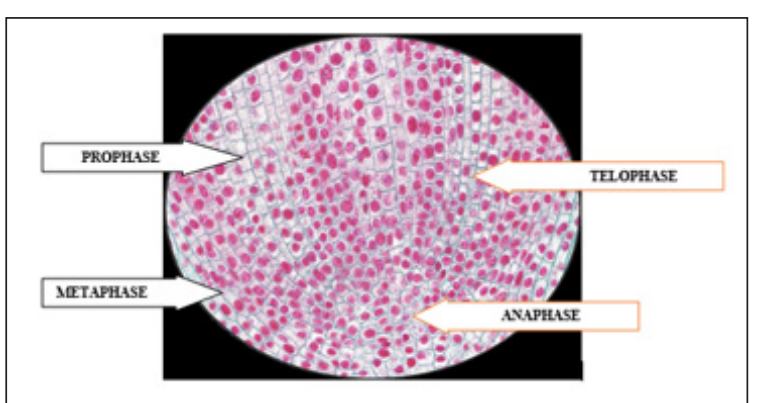

Figure 1: Different stage of mitosis of Allium cepa roots after treatment with water (Control).

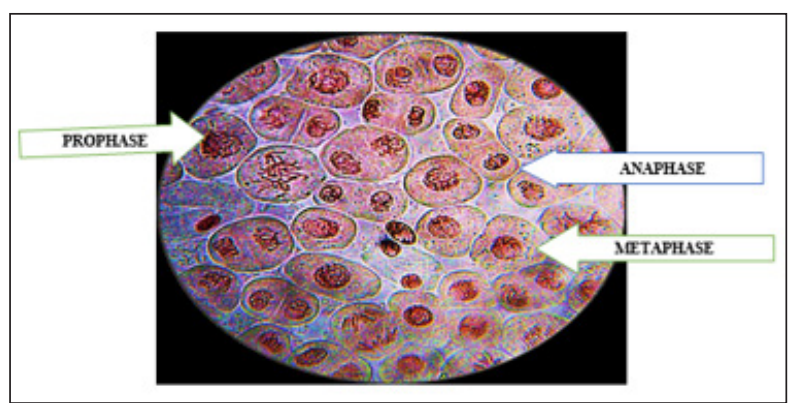

Figure 2: Different stage of mitosis of Allium cepa roots after treatment with Methotrexate (Standard drug).

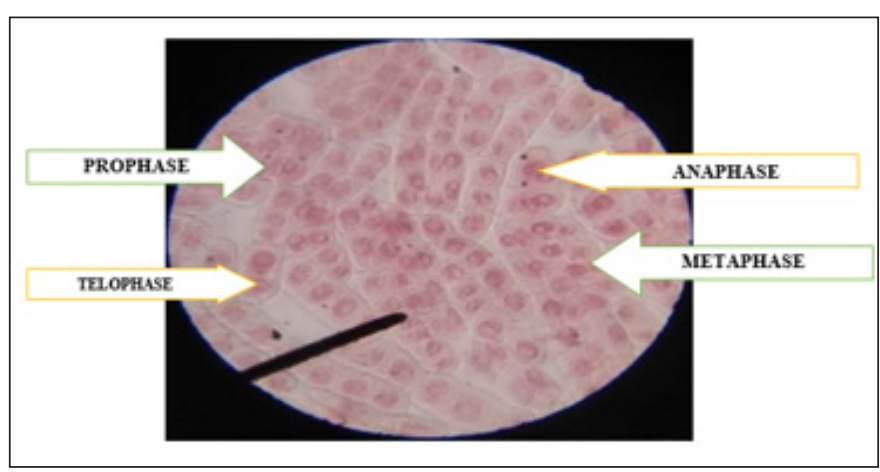

Figure 3: Different stage of mitosis of Allium cepa roots after Treatment with $10 \mathrm{mg} / \mathrm{ml}$ concentration of aqueous extract of Ficus Benghalensis Linn. Root 


\section{Antimitotic Activity}

Antimitotic agents are the compounds that arrest cells multiplication in mitosis. In the antimitotic assay, aqueous extracts of Ficus benghalensis roots showed good inhibition of meristematic cell during different stages of the cell cycle [Figure 3]. The \% mitotic index was found to be $22 \pm 1.15$ for aqueous extracts of Ficus benghalensis Linn. roots which was close to standard, methotrexate $30 \pm 1.35$ was shown in ( Table 2) (Figure 3).

\section{Discussion}

The Ficus benghalensis Linn. root shows wide spectrum of medicinal activities. The plant contains various phytoconstituents having diverse chemical structure and nature. The main active constituents are found in plants as phenolic, flavonoids and tannins compound. It is widely reported by many researchers that any compound with strong antioxidant property will also have potential anticancer properties because of the role of free radicals in the development of cancer [16]. Phenolic compounds have been reputed for their antioxidant ability [17]. In our study, polyphenolic compounds were mainly found in Ficus benghalensis Linn. by using total phenolic content by Folin-Ciocalteu assay. In existing study, Allium cepa root meristamatic cell model is used to study antimitotic property of Ficus benghalensis Linn. root in $10 \mathrm{mg} / \mathrm{ml}$ concentration $[18,19]$. In this parameters, division of cells is same as that of division of cancerous cells in human being. Therefore, these cells are used to study antimitotic activity in different parts of plants. Allium cepa meristamatic cells assay is fast, quick to detect toxicity in cells and toxicity in cells genetic material. The inhibition of root growth and antimitotic property gives indication of destruction of cells genetic material. The destruction of cells of genetic material assay action on Allium cepa as a plant helpful in studying karyo type of plant and skill to connect with those of mammalian cells in toxic evaluation. The good genotoxic assay performance of Allium cepa as a plant system has been attributed to the easily studied karyo type of plant and the ability to correlate outcomes of assays with those of mammalian cells in the course toxic evaluations [20] In Allium cepa assay, aqueous extracts of Ficus benghalensis Linn. root $(10 \mathrm{mg} / \mathrm{ml})$ was found to inhibit root growth in Allium cepa root meristamatic cells and decreased mitotic index after treatment.This suggests that the aqueous extract of Ficus benghalensis Linn. roots have fair antimitotic potential in concentration of $10 \mathrm{mg} / \mathrm{ml}$. In Allium cepa assay, MI (mitotic index) is considered as an indication of biomarkers cells proliferation in metaphase cell cycle [21,22] (Graph).

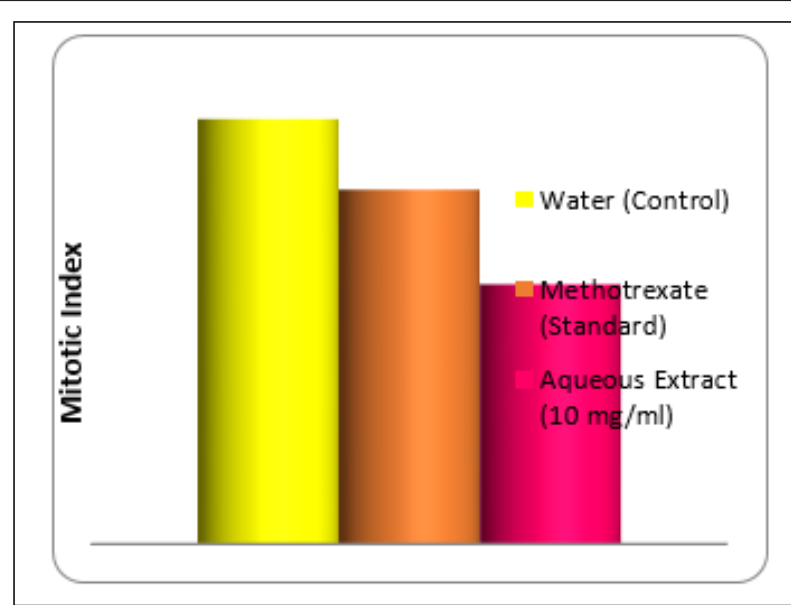

Graph: Mitotic index of water (control), methotrexate and $10 \mathrm{mg} / \mathrm{ml}$ concentration of aqueous extracts of Ficus benghalensis Linn. Root.

\section{Conclusion}

Our finding supports that $10 \mathrm{mg} / \mathrm{ml}$ concentration of aqueous extracts of Ficus Benghalensis roots inhibits cell division in Allium cepa meristamatic cells and may helpful in inhibiting abnormal cell growth like cancerous cells. Further experiments are needed, both in vitro and in vivo to obtain detail mechanisms of action. Positive outcomes from study introduce this plant as a new anticancer drug.

\section{Acknowledgement}

Authors are thankful to Principal of College of Pharmacy, Shahada-425409, Maharashtra for their help and support to complete the research work.

\section{Conflicting Interest}

There are no conflicts of interest.

\section{References}

1. Cragg GM, Newman DJ (2005) Plants as a source of anticancer agents. J Ethnopharmacol 100(1-2): 72-79.

2. Lee KH (2010) Discovery and development of natural product derived chemotherapeutic agents based on a medicinal chemistry approach. J Nat Prod 73(3): 500-516.

3. Li JW, Vederas, JC (2009) Drug discovery and natural products: end of an era or an endless frontier? Science 325(5937): 161-165.

4. Newman DJ, Cragg GM, Snader KM (2003) Natural products as sources of new drugs over the period 1981-2002. J Nat Prod 66 (7): 1022-1037.

5. Gonzales GF, Valerio LG (2006) Medicinal plants from Peru: a review of plants as potential agents against cancer. Antican. Agents Med Chem 6(5): 429-444.

6. Chopra RN, Nayar SL, Chopra IC (1996) In Glossary of Indianmedicinal plants, National Institute of Science Communication. New Delhi, India 169. 
7. Chaudhary S, Alok S, Jain SK, Chanchal D, Dongray, A ( 2015) Phytopharmacology and pharmacognostic properties of Ficus benghalensis-a review. International Journal of Pharmacognosy 2(12): 560-569.

8. Patil VV, Bhangle SC, Narkhede BS, Jawle NM, Patil RV (2010) Analgesic and Antipyretic Activities of Ficus bengalensis Bark. International Journal of Pharmaceutical Research 2(2): 25-30.

9. Manocha N, Samanta CK, Sharma V (2011) Evaluation of anti-rheumatic activity of extract of stem bark of Ficus bengalensis. Journal of Global Pharma Technology 3(3): 31-37.

10. Raheel R, Siddiqe Z, Iram M, Afzal S (2011) In vitro antimitotic, antiproliferative and antioxidant activity of stem bark extracts of Ficus Benghalensis L. South African Journal of Botany 111: 248-257.

11. Kokate CK, Purohit AP, Gokhale, SB (1999) Textbook of Pharmacognosy. 11th Edition, Nirali Prakashan, Pune, p. 225-226.

12. Harborne, JB (2000) Phytochemical methods: A guide to modern techniques of plant analysis. 3rd Edition. Chapman and Hall Publishing House, New Delhi.

13. Ahirrao RA, Patange BS, More SV (2019) Evaluation of Antimitotic Activity of Momordica Dioica Fruits on Allium Cepa Root Meristamatic cells. Journal of Pharmaceutical Technology Research and Management 7(2): 67-71.

14. Patil SG, Patil PS, Patil VR, Ahirrao RA (2018) Study of Antimitotic activity of Murraya Koenigii by Using Allium Cepa Root Tip Assay. European Journal of Pharmaceutical and Medical Research 5(9): 286-289.
15. Kulkarni SK (1993) Handbook of experimental pharmacology, 2nd Edition, VallabhPrakashan, Mumbai, p. 172-189.

16. Kaur C, Kapoor HC. Antioxidants in fruits and vegetables -The millennium's health. Int J Food Sci Tech 36:703-25.

17. Kalaskar MG, Surana SJ (2011) Free radical scavenging and hepatoprotective potential of Ficus microcarpa L. fil. bark extracts. J Nat Med 65(34): 633-640.

18. Abhang RY, Joglekar PP, Kulkarni PH (1991) Preliminary study on the effect of T. cordifoliaon mitosis. Anc Sci Life 11(1-2): 7-8.

19. Latha PG, Chandralekha CT, Vilasini G, Panikkar KR (1998) Effects of the flower extract of Ixoracoccinea Linn. on the meristamatic cells Allium cepa. AncSci Life 17(4): 262-267.

20. Fiskesjo G (1985) The Allium test as a standard in environmental monitoring. Hereditas 102(1): 99-112.

21. Bhattacharya S, Haldar PK (2012) Evaluation of antimitotic and genotoxic effects of the triterpenoid enriched extract from Trichosanthes dioica root. Am-Euras J of Toxicol Sci 4(1): 20-23.

22. Periyanayagam, K, Kasirajan B, Karthikeyan V, Indumathi R, Kumuda T (2013) Vitisvinifera L (Vitaceae) fruits towards antimitotic and antiproliferative activity in anticancer drug discovery. Innovare J Health Sci 1(3): $32-35$ 